\title{
The Implementation of Kahoot in Improving Students' Tenses Understanding in Higher Education
}

\author{
Nurlaela ${ }^{1, a *} \&$ Syahrianti M Nawir ${ }^{1, b}$, \\ ${ }^{1}$ Department of Guidance and Counseling, Faculty of Teachers Training and Education, Universitas Tompotika \\ Luwuk, Sulawesi Tengah, Indonesia \\ a elachryzna@gmail.com; b syahriantinawir@gmail.com \\ *Corresponding Author: elachryzna@gmail.com | Phone:085231613747
}

\begin{abstract}
Tense is a part of English grammar that becomes something difficult to understand by students. Therefore, it needs interesting and creative learning media to face that problem. This research purposes to evaluate and analyze the implementation of Kahoot as a digital learning media in improving students' understanding about tenses in higher education. There were 15 students in Civic Department of Education Faculty in Universitas Tompotika Luwuk as the sample of this research. Mix method in concurrent embedded strategy design was chosen as methodology of research. Quantitative data was collected through test, while qualitative data was collected by observation and interview. Hypothesis testing and descriptive analysis was conducted as analyzing technique. The quantitative result found that there was the improvement of students' study result about tenses from pretest to posttest. The value of $t$-count $(9,5176)$ which is greater than the value of $t$-table $(2,048)$ is the proof. Moreover, quantitative result was supported by qualitative analysis result. It was proved by students' achievement towards understanding indicators, namely translation, interpretation, and extrapolation. This research expected becomes contribution for the teachers and learners for implemented Kahoot as an interesting and creative learning media.
\end{abstract}

Keywords: Kahoot; Study result; Students' understanding; Tenses;

\section{Introduction}

Tense is being a part of English grammar (Tomakin, 2014). It is an important thing in understanding grammar. Shiny (2013) stated that tense is used to express the location or an event or state in time in composing sentence. Sentence can categorized grammatically correct if it is appropriate with the tenses. The fact, tense is something difficult to understand by the students in Indonesia, especially in Tompotika Luwuk University. Almost of them compose ungrammatical sentences in writing and speaking. According to them, it is complex thing for composing grammatical sentence in English. Of course, it is because the different of sentence pattern among English and Indonesia. In line with this Inayati \& Damayanti (2016) stated that English has its own sentence structure that different with Indonesia sentence structure, so it gives difficulties for the learners. Moreover, Pereira \& Mosa (2017) pointed that there are a great variety of tenses in English; the students should understand all of the tenses for supporting their language skills. There are sixteen kinds of tenses that the students' should understand. Therefore, it needs appropriate technique for students' in understanding tenses.

There were a lot of approaches that implemented by researchers for solved tenses problem. Jubhari (2018) found that students' can mastery tenses well by implemented substitution drill technique in the learning process. Rusdi \& Hafid (2016) claimed that it was very effective in learning tenses through the crossing formulas of tenses table. In Addition, Isna (2018) found that animated movie "Up" was proper for teacher to teach about several types of tenses, namely simple present tense, present perfect tense, present progressive tense, simple past tense, past progressive tense, and simple future tense, and. Moreover, Hayati \& Devanti (2016) pointed that using English song can improve students' simple tenses mastery. The best technique in teaching tenses that become a complex thing for the students is when it was enjoyable and closer with their life. Technologies utilization in learning process is recommended implemented. One of them is Kahoot. Kahoot is a result development of technology. It is a fun game based learning that easy in creating, sharing, and playing learning game. Kahoot is the best practice of education that can integrate and 
create competitive environment (Dellos, 2015). Indeed, it is a digital game based learning that can implement in the learning process. As a digital game, Kahoot presents questions to the students. Heni et al (2019) said that Kahoot is an online game that teach and test students' knowledge through questions. Additionally, Omar (2017) stated that kahoot application provides a platform for educators to create a more engaging way to access learners' knowledge on any given subjects. Moreover, Lin et al (2018) claimed Kahoot to be beneficial in term of fostering and reinforcing learning. Actually, Kahoot is not only consisting of questions, but also it can serve a material as the learning topic. It means that Kahoot as an interactive learning media can serves a lot of learning activities such as pretest, material concept mastery, questions game, remedial, and posttest. Teachers or lecturers can design their own material by create an interesting slide or quiz. A lot of material can be taught through it, include material about tenses.

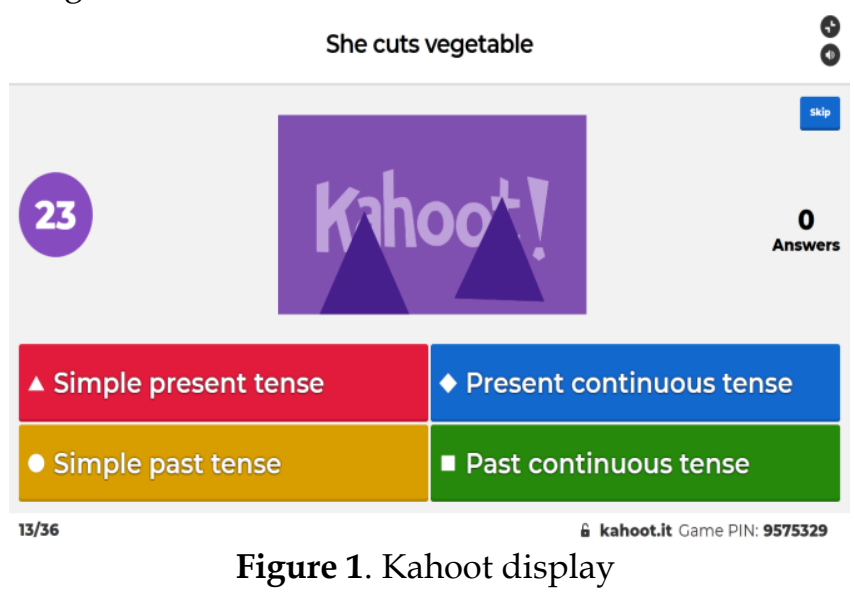

Implementation Kahoot in the learning process is a solution of students' problem in tenses understanding. Kahoot was expected can improve students understanding about tenses. It can be shown from two aspects, namely students' study result and students' learning behavior in the learning process. Cahyati (2010) claimed that students' understanding is study result where the indicators such as understanding the concept, can explaining, defining, and interpreting information by using own words. According to Bloom, understanding is higher than knowledge (Nana Sudjana, 2016). In Addition, Sudijono (2015) claimed that understanding is student's ability in knowing and understanding of something. In line with this, Bloom in Muqarrabin (2020) was classified understanding indicator in three points. They are translation, Interpretation, and extrapolation. Translation point consists of defining, translating, explaining, and modifying. Interpretation consists of interpreting, distinguishing, explaining, and describing. Then, extrapolation consists of expecting, distinguishing, filling, determining, and summarizing.

Finally, the researcher excited to conduct research about the implementation of Kahoot in improving students' tenses understanding in higher education, with the purpose is to evaluate and analyze students' study result and students' understanding about tenses in the learning process.

\section{Methods}

\subsection{Research Design}

Mix method with concurrent embedded strategy design was chosen as research design in this study. Quantitative method was the primary method that used one group pretest and posttest design, while qualitative method was the secondary method that used descriptive analysis. It means that qualitative data was supported quantitative data.

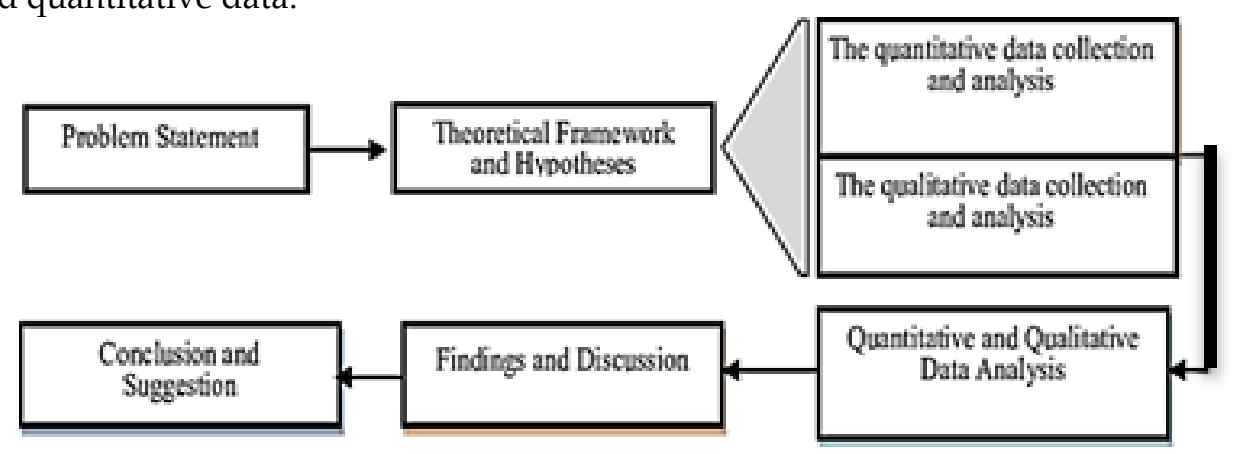

Figure 2. Concurrent Embedded Strategy by Sugiyono (Sugiyono, 2013) 


\subsection{Population and Sample}

Population of this research was students in Teacher Training and Education Faculty of Tompotika Luwuk University. Sample of this research was 15 students of civic department of Teacher Training and Education Faculty of Tompotika Luwuk University in the second semester who passed English I subject. They were chosen by using purposive sampling

\subsection{Procedure of Data Collection}

Data was collected by test, observation, and interview. Test conducted for get quantitative data, while observation and interview conducted as instrument for get qualitative data. Firstly, the researcher gave preliminary test to the students before doing an action. Furthermore, the researcher did an action namely implemented Kahoot in the learning process. Observation was done in the action process simultaneously. After did an action three times, posttest was given to the students. The last procedure was interviewed the students about their tenses understanding based on the indicators that have been conducted.

\subsection{Data Analysis}

Data was analyzed through quantitative and qualitative. In quantitative there are five steps in analyzing it. They are validity test for getting valid instruments, reliability test for examine the consistent of the instrument, normality test for categorized the instrument in normal distribution, homogeneity test for homogeneity varians, and t-test for answer the hypothesis (Arikunto, 1998). Moreover, qualitative data was analyzing by data reduction, data display, and conclusion. Those analyzing steps were proposed by Miles and Huberman Theory.

\section{Results and Discussions}

This research finding showed that implementation Kahoot in the learning process can improve students' understanding about tenses. It can be proved by students study result in the pretest and posttest. There was improvement from pretest score to the posttest score. In the pretest, it displayed that the students' study result majority in low score. The pretest result can be seen in the table 1 .

Table 1. Frequency distribution of students' study result in pretest

\begin{tabular}{cccccccr}
\hline $\begin{array}{c}\text { Interval } \\
\text { Class }\end{array}$ & $\left(f_{i}\right)$ & $(\mathrm{xi})$ & $f_{i} x_{i}$ & $\left(x_{i}-\bar{x}\right)$ & $\left(x_{i}-\bar{x}\right)^{2}$ & $f_{i}\left(x_{i}-\bar{x}\right)^{2}$ & Relative Frequency (\%) \\
\hline $3-5$ & 3 & 4 & 12 & -4.2 & 17.64 & 52.92 & 20 \\
\hline $6-8$ & 7 & 7 & 49 & -1.2 & 1.44 & 10.08 & 46.66667 \\
\hline $9-11$ & 1 & 10 & 10 & 1.8 & 3.24 & 9.24 & 26.66667 \\
\hline $12-14$ & 4 & 13 & 52 & 4.8 & 23.04 & 158.4 & 100 \\
\hline Total & 15 & 123 & \multicolumn{7}{c}{ Note $: f_{i}$ = frequency $; x i=$ median; $x=$ mean }
\end{tabular}

From 16 questions that have been given, it performed 7 students get in interval class 6-8, and 3 students included in interval class 3-5. It means that students' understanding about tenses categorized in low. After implemented Kahoot in the learning process, the posttest was given. Furthermore, the result of posttest was changed. The improvement of students' study result was occurred in posttest. The result of posttest can be seen in the table 2.

Table 2. Frequency distribution of students' study result in posttest

\begin{tabular}{cccccccc}
\hline $\begin{array}{c}\text { Interval } \\
\text { Class }\end{array}$ & $\left(f_{i}\right)$ & $(\mathrm{xi})$ & $f_{i} x_{i}$ & $\left(x_{i}-\bar{x}\right)$ & $\left(x_{i}-\bar{x}\right)^{2}$ & $f_{i}\left(x_{i}-\bar{x}\right)^{2}$ & Relative Frequency (\%) \\
\hline $8-9$ & 1 & 8.5 & 8.5 & -5.33 & 28.44 & 28.44 & 6.67 \\
\hline $10-11$ & 1 & 10.5 & 10.5 & -3.33 & 11.11 & 11.11 & 6.67 \\
\hline $12-13$ & 4 & 12.5 & 50 & -1.33 & 1.78 & 2.11 & 3.67 \\
\hline $14-15$ & 5 & 14.5 & 72.5 & 0.68 & 0.44 & 2.22 & 26.67 \\
\hline $16-17$ & 4 & 16.5 & 66 & 2.67 & 7.11 & 77.33 & 100 \\
\hline Total & 15 & \multicolumn{7}{c}{207.5} & & & \\
\hline
\end{tabular}

Note : $f_{i}=$ frequency $; \mathrm{xi}=$ median; $x=$ mean

Significant improvement occurred in the posttest. It proved by the highest point in the interval class, namely 16-17. There are 4 students get the highest point. Besides that, there was only 1students included in class interval 8-9. The improvement also can be seen from the mean score of pretest and posttest. The result of pretest and posttest are provided in table 3. 
Table 3. Comparison of students' study result in pretest and posttest

\begin{tabular}{ccc}
\hline Components & Pretest & Posttest \\
\hline $\mathrm{N}$ & 15 & 15 \\
\hline Mean & 8.2 & 13.83 \\
\hline Modus & 6.7 & 14.5 \\
\hline Median & 7.43 & 14.1 \\
\hline Standard Deviation & 3.25 & 2.27 \\
\hline
\end{tabular}

Test analysis was performed that the mean of pretest categorized in low. It was 8,2 . The improvement occurred in the posttest. The mean of posttest was 13,83. It showed the significant improvement from pretest to posttest. Moreover, it claimed that students' understanding about tenses was improved by considered the value of $t$-count. The $t$-count value $(9,5176)$ which is greater than the $t$-table value $(2,048)$ with the level significance 0,05 is the proof. In line with this, Alfansyur \& Mariyani (2019) found that students' study result after implemented Kahoot have improved from pretest to posttest.

Those study result was supported by observation and interview result. From observation, it found that alteration was happened in the learning process after implemented Kahoot as a learning media. The general observation result is provided in the table 4 .

Table 4. The General Observation Result

\begin{tabular}{|c|c|}
\hline Indicators & Observation results \\
\hline Translation & $\begin{array}{l}\text { There were the different views between before and after implemented Kahoot as the learning media. Firstly, almost } \\
\text { the students only understand about simple present tense and simple past tense. They did not understand about the } \\
\text { other tenses, although they have learnt about the tenses in the first semester. Moreover, when the lecture tried to } \\
\text { explain about the tenses through speech, they look did not enthusiasm. Different view when the Kahoot was } \\
\text { implemented in the learning process in the game form. The students look enthusiasm, excited, nodding head as } \\
\text { understanding sign, and sometimes gave their opinion about the correct answer. They also capable in giving } \\
\text { definition about the tenses by using their own words. In addition, they capable change sentence in one tense patter } \\
\text { to the other tense pattern, such as the sentence in the simple present tense form change to present continuous tense } \\
\text { form. }\end{array}$ \\
\hline Interp & $\begin{array}{l}\text { After implemented Kahoot, students able to interpreted the meaning of the sentences that have given by the lecture. } \\
\text { When in the Kahoot primary screen showed sentences (1) I studied English, and (2) I will be studying English, they } \\
\text { capable to interpreted that in the sentence (1) the activity of "study" have been finished in the past time, and } \\
\text { sentence (2) the activity of "study" will occur in the future for an expected time. Additionally, the students capable } \\
\text { distinguished the sentence which is formed by different pattern of tenses. Moreover, they also capable described an } \\
\text { activity in a sentence form based on the tenses pattern. For example, when there was the sentence "He drove a car" } \\
\text { they capable to described that the activity of "drive" have been finished in the past time. }\end{array}$ \\
\hline Extrapolation & $\begin{array}{l}\text { Students able to summarized their understanding about the whole tenses. They capable in giving the definition of } \\
\text { tenses by using their own words. They capable to explain the meaning of the tenses and also the sentences that } \\
\text { formed by all tenses pattern. They also capable composed sentence by used all kinds of tenses pattern. When they } \\
\text { faced a sentence, they able to guess the tense pattern that composed the sentence. For example, when the Kahoot } \\
\text { showed the sentence "I was listening the music", almost of them guessed that the sentence is formed by past } \\
\text { continuous tense pattern. Moreover, they also capable distinguished the different kinds of tenses that formed in } \\
\text { sentences, and able determined the sentences that formed by the different tenses. Indeed, almost of students capable } \\
\text { in expecting, distinguishing, filling, determining, and summarizing about tenses. }\end{array}$ \\
\hline
\end{tabular}

Before implemented Kahoot in the learning process, students looked confused when the researchers asked questions about tenses. There were seven students can explained only three kinds of tenses. Different view came when the researcher implemented Kahoot as a learning media. The students looked enthusiastic, enjoyable, nodding head, and sometimes gave their opinion about the correct answer in the Kahoot. Previous research finding (Setiawati, Sikahbuden, \& Ali, 2020) showed similar result, they claimed that Kahoot as a learning media is effectively used in the learning process because it create enjoyable and creative learning. Sabandar et al (2018), claimed that this Kahoot game will be useful not only to review the material that they will present later in the learning process but also will create an interactive and fun classroom. In line with this, Rafnis (2018) pointed that Kahoot is an interesting learning media that should implemented in the learning process, because it can solve students' boredom. When the students were enjoyed the learning process, automatically it was easier for them in understanding the material that given by the lecture. The use of Kahoot as the learning media can foster student's interest and motivation, then finally their knowledge also can be improved (Mada \& Anharudin, 2019). Students capable to explaining the kinds of tenses, modifying the sentence based on the tenses, interpreting sentences in all kinds of tenses, distinguishing each tenses, expecting what kinds of tenses that used in the sentences, and summarizing concept, formula, and example of all kinds of tenses. Clearly, the students categorized understand about tenses because they 
achieved the understanding indicator.

Moreover, from the interview result showed the significant improvement of students' tenses understanding after implemented Kahoot. It can be seen from the interview result of the respondent 1.

"Menarik bu,dan saya jadi paham. Menurut saya, kalau present tense itu berisi tentang aktifitas saat sekarang. Simple past tense aktifitas pada masa lampu seperti kemarin, dua tahun lalu. Sedangkan kalau simple future tense bu, menurut saya aktifitas yang baru direncanakan akan dilakukan nanti, besok, minggu depan, atau tahun depan."

(Yes, It is exciting and I understand, mom. According to me, simple present tense means that the activity happens right now. Simple past tense means that activity was happened in the past time. Simple future tense means that the activity will happen in the future such as tomorrow, next week, or next uear)

(Statement of R1, Friday, September $18^{\text {th }}, 2020$ )

In line with that statement, the respondent 2 also give similar perception and understanding toward Kahoot implementation in understanding tenses. It can be seen from the interview result of respondent2.

"Kalau saya belum pernah belajar pakai media Kahoot ini mam, jadi semangat dan saya paham mam, Misalnya kalau kalimat itu "saya sedang belajar bahasa Inggris tadi malam", dia harus pakai past continuous tense. Karena yang sementara berlangsung itu kegiatan belajar yang sudah dilakukan tadi malam. Jadi bentuk kalimatnya, "I was studying English".

(I never used Kahoot in my learning process before. I felt enthusiasm, and it make me understand about the tenses. For example in the sentence "I was studying English". It used past continuous tense. It because of the activity of "study" was occurring in the last night. So the sentence should be "I was studying English)

(Statement of R2, Friday, September 18th, 2020)

Additionally supported statement comes from Respondent 3.

"Bagus belajar pakai Kahoot mam. Bisa bermain sambil belajar, terus termotivasi torang harus bisa bajawab benar, supaya namanya saya bisa muncul di podium jadi urutan pertama. Jadi memang termotivasi jadi paham. Dan sekarang saya so paham mam, kalau yang kalimat ini bentuk simple past tense ibu karena pake verbII. Kalimat yang selanjutnya itu polanya future continuous karena ada "will be" dan "verb ing"." Begitu kan mam.

(It is better learning by using Kahoot mam. We can play game while studying. It also motivated me to give correct answer. I tried my name can be the first rank in the Kahoot podium. So, it made me understand about the material that you give to me. For example, this sentence is simple past tense, because it used "verb II" in the sentence. The next sentence is future continuous, because there were the words "will be" and "verb-ing". Isn'it mam)

(Statement of R3, Friday, September 18th, 2020)

Moreover, the other respondents also gave statement which is supported that the implementation of Kahoot in the learning process make them enjoy and easy to understanding material about tenses. Almost the students as the respondents of research confessed that they were excited learn about tenses when it taught by Kahoot. They felt interest and enjoy the tenses class because kahoot provide a lot of interesting features that support their motivation to understand tenses. Besides that, the utilization of their gadget for accessing kahoot in game form makes them more enthusiasm followed the learning process. As the result, when the lecturer checked their understanding about tenses through interview, they capable to showed their understanding achievement based on the indicators that proposed by Bloom.

\section{Conclusion}

Implementation of Kahoot as the learning media can improve students' tenses understanding in higher education. There are two important points which supported that statement. Firstly, students' study result was improved from pretest to post test. There was significant improvement from their pretest mean 8,2 to posttest mean 13,83 . The $t$-count value $(9,5176)$ which is greater than the $t$-table value $(2,048)$ with the level significance 0,05 also confirmed the improvement of students' study result. The second is students' behavior in the learning process. Almost students showed their achievement toward understanding indicator that purposed by Bloom, namely translation, interpretation, and extrapolation.

\section{Aknowledgement}

I would like to express my thankful to LLDIKTI for supported and funded this research, from the first stage until publication. 


\section{References}

Alfansyur, A. \& Mariyati. (2019). Pemanfaatan Media Berbasis ICT Kahoot Dalam Pembelajaran PPKN Untuk Meningkatkan Motivasi Belajar Siswa. Jurnal Bhineka Tunggal Ika, Vol. 6 (3). https://ejournal.unsri.ac.id/index.php/jbti/article/view/10118

Arikunto, S. (1998). Prosedur Penelitian Suatu pendekatan Praktek. Jakarta: Rineka Cipta.

Dellos, R. (2015). Kahoot!: A Digital Game Resources for Learning. International Journal of Instructional Technology and Distance Learning, Vol. $12 \quad$ (4), $\quad$ pp. http://www.itdl.org/journal/Apr_15/Apr_15.pdf

Hayati, N., \& Devanti, D.M. (2016). Improving Students' Tenses Mastery by Using English Song at MA Nurut Taqwa Cerme. International Conference of Education, Vol. 1 (1), pp. 89-95. http://jurnal.unmuhjember.ac.id/index.php/IECO/article/view/504/426

Heni, V., Sudarsana, \& Regina. (2018). Using Kahoot to Increase Students' Engagement and Active Learning: A Game Based Technology to Senior High School Students. Proceeding International Conference on $\begin{array}{llllll}\text { Teaching and } & \text { Education, } & \text { Vol. } & \text { 129-134. }\end{array}$ https://jurnal.untan.ac.id/index.php/icote/article/view/33949

Inayanti, A.M., \& Damayanti, D. (2016). Improving Students' Grammar Ability (Simple Past Tense) Using Johny Grammar Word Challenge Application in Junior High School. Proceeding of the International Conference on Teacher Training and Education, Universitas Sebelas Maret, Vol. 2 (1), Pp. 876-881. https://jurnal.uns.ac.id/ictte/article/view/12378

Isna, N. (2018). An Analysis of Tenses Usage in Animated Movie "'Up": The Relevance With 2013 Curriculum for Teaching EFL at Junior High School in Indonesia. Englisia Journal of Language, $\begin{array}{lllll}\text { Education, and Humanities, } & \text { Vol } & 5 & \text { (2). } & \text { https://jurnal.ar- }\end{array}$ raniry.ac.id/index.php/englisia/article/view/2332/2235

Jubhari, Y. (2018). Improving Students' Tenses Mastery through Substitution Drill. SELTIC Journal, Vol. 1 (1), pp. 55-62. https://ejournals.umma.ac.id/index.php/seltics/article/view/47

Lin, D.T., Ganapath, \& Kaur, M. (2018). Kahoot! It: Gamification in Higher Education. Pertanika Journal of Social Science Humanities, Vol 26(1), pp.565-582. http://www.pertanika.upm.edu.my/view_archives.php?journal=JSSH-26-1-3

Mada, R.D., \& Anharudin. (2019). How Online Learning Evaluation (Kahoot) Affecting Students' Achievement \& Motivation (Case Study on it Students'). International Journal for Educational and Vocational Studies, Vol. 1 (5), pp. 422-427. http://ojs.unimal.ac.id/index.php/ijevs

Omar, N.N. (2017). The Effectiveness of Kahoot Application toward Students' Good Feedback Practice. International Journal of Social Sciences, Vol. $3 \quad$ (2), pp. 2551-2562. https://grdspublishing.org/index.php/people/article/view/849

Pereira, S. \& Andreas, M. (2017). A Study on The Ability to Use Simple Present Tense by The First Grade Students of Ensino Basico Central Prade Mauel Luis Maliana in The School Year 2017. Journal of Innovative Studies on Character and Education, Vol. 1 (1) http:/ / www.iscjournal.com/index.php/isce/article/view/8

Rafnis. (2018). Pemanfaatan Platform Kahoot Sebagai Media Pembelajaran Interactif. Jurnal Ilmiah Teknologi Pendidikan, Vol. 6 (2). http://ejournal.unp.ac.id/index.php/e-tech/article/view/101336

Rusdi, M., \& Hafid, A., G. (2016). The Effectiveness of Using Crossing Formula of Tenses Table in Learning English Tenses at XII Grade Students of MA Madani Alaudin Paopao in Academic Year of 2015/2016. English, Teaching, Learning and Research Journal, Vol. 2 (1). http://journal.uinalauddin.ac.id/index.php/Eternal/article/view/2386

Sabandar, G.N.C., Supit, N.R., \& Suryana, E. (2018). Kahoot!: Bring the Fun into the Classroom. Indonesian Journal of Informatics Education, Vol. $2 \quad$ (2), $\quad$ pp. $\quad 127-134$. https://jurnal.uns.ac.id/ijie/article/view/26244

Setiawati, H.D., Sihkabuden, \& Adi, E.P. (2020). Pengaruh Kahoot Terhadap Hasil Belajar Siswa Kelas XI di SMAN 1 Blitar. JKTP, Vol. 1 (4). http://journal2.um.ac.id/index.php/jktp/article/view/5816

Shiny, K.P. (2013). Time and Tense: A Critical Review of Literature. International Journal of English and Education, Vol. 2 (2), pp. 32-41. http://ijee.org/vol_2_issue_2

Sudjana, N. (2016). Penilaian Hasil Proses Belajar Mengajar. Bandung: PT REMAJA ROSDAKARYA.

Sudijono, A. (2015). Pengantar Evaluasi Pendidikan. Jakarta: Rajawali Pers Raja Grafindo Persada.

Sugiyono. (2013). Cara Mudah Menyusun Skripsi, Tesis, dan Disertasi. ALFABETA Bandung. ISBN.9786027825-84-0.

Tomakin, E. (2014). Teaching English Tenses (Grammar) in The Turkish Text: A Case of Simple Present Tense. International Journal of Learning and Development, Vol. 4 (1), pp. 115-131. http://www.macrothink.org/journal/index.php/ijld/article/view/5154/4274 